\title{
A FÖLDRAJZOKTATÁS JELENLÉTI ÉS ONLINE FORMÁINAK
}

\section{TAPASZTALATAI}

\section{Szerzők:}

Simonyi Sándor Rajmond

Eszterházy Károly Egyetem

Szerző e-mail címe:

sandor.simonyi95@gmail.com

\section{Lektorok:}

Homoki Erika (PhD)

Eszterházy Károly Egyetem

Sütő László (PhD)

Eszterházy Károly Egyetem

és további két anonim lektor...

\begin{abstract}
Absztrakt
A jelenlegi kutatás fókuszában a kiválasztott közoktatási intézmények infrastrukturális felszereltségének vizsgálata állt, ezen belül is a digitális eszközökkel való ellátottság. A kutatás a Covid-19 járvány előtt kezdődött el, majd az első eredmények alapján egy újabb digitális kérdőív elkészítésére került sor a megváltozott oktatási környezet módszertani változásait kutatva. Kíváncsiak voltunk a tanároknak a tantermen kívüli (online) oktatásról alkotott véleményére. Olyan kérdésekre kerestük a választ, hogy készen áll-e a magyar közoktatás az online tanításra? Milyen előnyeit és hátrányait látják az „újfajta” tanítási környezetnek? A kitöltő pedagógusok 75\%-a úgy vélekedett, hogy Magyarországon az elkövetkezendő 5-10 évben lesz teljesen, problémamentesen kivitelezhető a virtuális osztályterem, a zökkenőmentes digitális oktatás minden iskolatípus számára.
\end{abstract}

Kulcsszavak: oktatási módszerek, digitális oktatás, infrastruktúra, oktatás helyzete hatékonysága

Diszciplína: társadalomtudomány, pedagógia

\section{Abstract \\ EXPERIENCES OF FACE-TO-FACE AND ONLINE FORMS \\ OF GEOGR APHY EDUCATION}

Ours current research focuses on the infrastructural equipment and digital tools of the chosen institutes. We began the examinations before the Covid-19 pandemic then we compiled another digital survey in order to explore the changes caused by the 
altered educational environment. We were curious to hear the opinion of teachers concerning the online education that does not take place in the classroom. We were desperate to find the answers for questions like: Is the Hungarian public education ready for teaching online? What are the advantages and disadvantages of this novel teaching environment? $75 \%$ of the teachers who filled in the survey shared the view that a completely problem free virtual classroom and seamless online education would only be available for all types of schools in the next 5 to 10 years.

Keywords: educational methods, digital education, infrastructure, effectiveness of education

Discipline: social science, pedagogy

Simonyi Sándor Rajmond (2021): A földrajzoktatás jelenléti és online formáinak tapasztalatai. OxIPO - interdiszciplináris tudományos folyóirat, 2021/2, 89-104. doi: 10.35405/OXIPO.2021.2.89

„Egy olyan tanárnak, aki a lelkét is beleteszi a tanításba, mindig megvan a hozadéka. Ott a diákok máshogy állnak a dolgokhoz.” (Lovász László)

Lovász László szavaival élve szeretnénk megerősíteni, hogy ha egy tanár szívétlelkét beleteszi a tanításba, akkor arra a pedagógusra másként fognak tekinteni a diákok. Úgy gondoljuk, hogy a pedagógusi hivatás az egyik legjelentősebb a világban. Miért? A jövőnk szempontjából kiemelten fontos feladatuk van a tanároknak, hiszen ők azok, akik segítik a jövő generációját a tudás megszerzésében és példaképként is szolgálnak nekik.

\section{Probléma, cél és kérdések}

A jelenlegi oktatás több problémával küzd, melyet Kis-Tóth és Hauser (2008) is megfogalmazott, véleményük a mai napig helytálló:

1. A tanulók különböző szintű tudással, képességgel, eltérô érdeklődési körrel rendelkeznek, tehát egységes kezelésük elfedi a közöttük lévő különbségeket, csökkenti a tanítás hatékonyságát.

2. A tanárok felkészültsége, alkalmazott módszereik, követelményük is eltérô, amelyet tovább korlátoz az adott intézmény infrastruktúrája, mely a jelen oktatás körülményeit erőteljesen befolyásolja (Forgó, Kis-Tóth és Hauser, 2008).

A tanárok és diákok mellett az iskola, mint intézmény is meghatározó. Napjainkban egyre több alternatív pedagógiát követő iskola jelenik meg. Az oktatási intézmények országos rangsorban elért pozícióját minden évben elkészíti az Eduline (Net1). Véleményünk szerint a rangsorban elfoglalt előkelő helyezés ma- 
gával hozza, hogy ezen iskolák jobb infrastruktúrájúak, jobb felszereltségűek is, amely elősegíti/elősegítheti a tanulók ismeretelsajátítását a tananyagrögzítését, rendszerezését.

Ezzel kapcsolatban az alábbiakban különböző típusú iskolák oktatási módszereit, infrastruktúráját vizsgáljuk meg személyes megfigyelés és kérdőívezés módszerét használva a földrajzoktatás jelenléti és online formáinak aspektusából. $\mathrm{Az}$ alábbi két hipotézist szeretnénk kiemelni, amelyeket a digitális oktatás során több kérdéssel egészítettünk ki:

1. Az oktatásban a változatos módszer és munkaforma alkalmazása hatékonyabb ismeret elsajátítást eredményez.

2. Az infrastrukturális berendezések hiánya ronthatja az oktatás színvonalát, és nehezítheti az ismeretek elsajátítását.

Kérdések: Az a diák, aki nem rendelkezik IKT eszközökkel, otthonukban nincs megfelelő asztali számítógép, telefon, laptop, ő hogyan fogja elsajátítani a tananyagot?

Mennyire érzik sikeresnek a pedagógusok a digitális oktatást?

Kaptak-e felkészítést az online órák megtartására?

\section{Minta}

A kutatás során összesen öt különböző típusú iskolát látogattunk meg (állami gimnázium, alternatív gimnázium, gyakorló iskola, speciális általános iskola), amelyek eltérő rangú településen helyezkednek el (főváros, megyeszékhely, kis város). Ahhoz, hogy a kutatási kérdéseket szélesebb körben is feltehessük készítettünk egy kérdőívet, amelyet az ország földrajz szakos pedagógusai közül 122 fő töltött ki. Megállapítható volt, hogy a legtöbb válaszadó a fővárosból (17\%), majd a megyeszékhelyekről érkezett, amelyek közül Szeged (6,5\%), illetve Eger, Nyíregyháza és Szolnok (2,5\%) emelkedett ki. A többi kisebb település részaránya már nem éri el az 1\%-ot, hiszen a legtöbb településen egy iskola egy tanárral fordul elő a mintában. A kitöltők főiskolai vagy egyetemi BA (28\%) és MA (57\%) végzettséggel rendelkeznek. Ennél magasabb végzettséggel (PhD, egyetemi szakirányú tovább képzés) a kitöltők 8,1\%-a bír. Bologna rendszerű tanárképzéssel 4,9\%, míg az osztatlan tanárképzés által mindössze 0,81\%-a szerzett diplomát, a többiek korábban végeztek, ez is bizonyítja a tanári pálya elöregedését (Hajdu Miklós, 2020; Homoki és Sütő, 2014). Ebből általános iskolában tanít 19,7\% , középiskolában 56,6\%-a. Összesen a válaszadók 27\%-a végzett bármilyen általános iskolai tanár szakon, míg középiskolain 61\%. A maradék 10 \% között szerepel földrajz tanítói kiegészítő-; szociológus-; tanító, tanár és művelődésszervező pedagógus. Később, 2020 tavaszán, a megváltozott tanulási környezetet vizsgálva egy újabb online kérdőív elkészítésére került sor, amely a koronavírus által kialakított online tanítást és annak sikerességét mérte. Ezt összesen 192 pedagógus töltötte ki országszerte. A kitöltők többsége Budapesten tanít (22,3\%), de nagy számban jelentek meg 
telephelyként Magyarország megyeszékhelyei, nagyobb városai (36,9\%) (pl.: Eger, Miskolc stb.) is; sőt az online változatnak köszönhetően kisebb városokból (például: Tata, Vác, Tiszaföldvár, Cegléd stb.); falvakból (Jászkarajenő stb.) és határon túli magyar településekről is érkeztek válaszok (például: Csíkszereda, Székelyudvarhely $-2,6 \%$ ).

A válaszadók többsége nő (88,5\%), a férfiak csak a válaszadó 12,5\%-át tették ki, életkori megoszlásuk az 1. ábrán látható.

\section{Módszer}

A választott módszer a kvalitatív módszerek közé sorolhatóak (hospitálás, interjú, kérdőív - v.ö..: Babbie, 2003; Falus és Ollé, 2000; Falus, 2007).

A kutatást egy félig strukturált hospi- tálással és félig kötött interjúval kezdtük, majd online kérdőíveket készítettünk a fentebbi kutatásmódszertani művek felhasználásával.

Fontosnak tartottuk, hogy ezek az iskolák településrangsori szempontból is változatosak legyenek, így fővárosi, megyeszékhelyi, mezővárosi, falusi iskolákat kértünk fel az együttműködésre. Fenntartói szempontból egy speciális általánosiskola, két állami gimnázium, egy gyakorló- valamint egy magániskola falai között vizsgálódtunk.

A hospitálások alapján eredményesnek ítélt és figyelemfelkeltő tanóra után fontosnak tartottuk a diákok véleményét is megvizsgálni, hogy melyik az az oktatási módszer (stratégia) vagy munkaforma, ami nekik és a tanárnak is élvezhető és ezáltal eredményes tanulási folyamatot ad.

1. ábra: A válaszadók életkorának megoszlása a két felmérés során (forrás: a Szerzó)

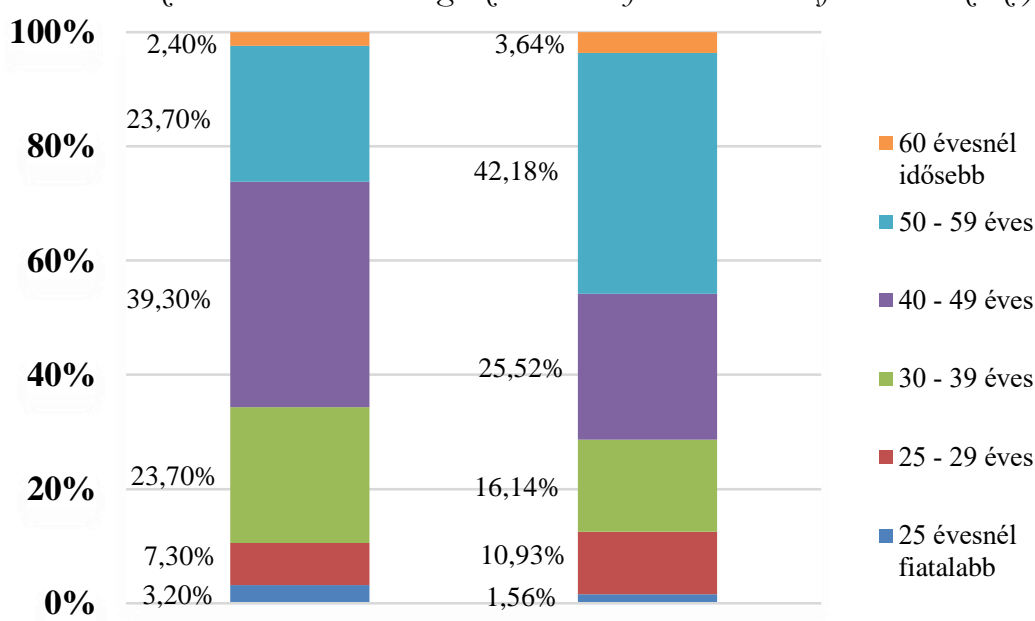

Mérés 1.

Mérés 2. 
Tényleg az iskola kiválasztásán van a hangsúly? Vagy inkább az alkalmazott módszereken, munkaformákon, tanári személyiségen és tanulói attitűdön? A mérések főként középiskolai tanulókkal zajlottak, de egy általános iskolában is vizsgálódtunk az ott alkalmazott egyedi oktatási stratégia miatt, ami a Komplex Instrukciós Program (KIP).

A KIP az Amerikai Egyesült Államokban került kidolgozásra. Célja az eredményesség, sikerélmény és a státusz kezelés (együttmúködés), amely a csoportmunka (heterogén) szervezésen alapszik. Fontos, hogy minden diák tudásszintje emelkedjen, továbbá aktív részese legyen a tanórának. A módszer elősegíti egy 45 perces tanóra keretein belül a differenciált oktatást. Lehetőség van a felzárkóztatásra és a tehetséggondozásra is, ugyanis a csoportfoglalkozások során a tanulók egyéni kérdéseket kapnak a saját készségeikhez képességeikhez mérten (K. Nagy, 2015a).

A kutatás OxIPO alapú megközelítés aspektusából a következők szerint értelmezhető. Didaktikai szempontból a bemenet (input) a célok megvalósítására alapszik (célképzés, oktatási tananyag). A digitális oktatás során az input (közlő) folyamat változott. A legtöbb pedagógus az ismeretek közlését - tartalmát csökkentette a diákok túlterheltsége miatt. Nem mindenhol volt/van lehetőség a digitális oktatás során online meetingre, így ilyen esetben a diákoknak önállóan kell(ett) elsajátítaniuk az újismereteket. A hagyományos oktatás során sem voltak az iskolák felszerelve megfelelő segédanyag- gal és felszerelésekkel - eszközökkel a tanórákhoz, amely nehezítette az oktatást (ezt a válaszadó pedagógusok 62,3\%-a jelölte meg mérséklet és komoly gondnak).

A feldolgozó (process) folyamat a tanár és a diák közös munkáját foglalja magában. A hagyományos oktatás során ez jól működik a tanórákon, amikor kialakul az interakció. A digitális oktatás ezt kevésbé teszi lehetővé. Megnehezíti a pedagógus részérôl a kapcsolat - interakció kialakítását az, hogy a tanulók bekapcsolt kamera nélkül vesznek részt a tanórán (amely gyakran felmerülő probléma).

Sok helyen nincs digitális eszköz a kapcsolat kialakítására, így nem tud megvalósulni a tanár és diák együttes tevékenysége (csak feladatok feladására kerül sor). Ezt bizonyíthatja, hogy a válaszadó tanárok közül 56,77\%-a közepesre, míg 12,50\%-a alacsonyra minősíti a sikerességét az online oktatás során.

A kimenet (output) az egyik legfontosabb a pedagógusok számára, mint viszszacsatolás. A online térben alkalmazott számonkérések (például időkorlátos feladatlapok, esszék stb.) nem a reális tudást mérik. A szóbeli feleletet, amely objektívabb eredményt adna, a kitöltő pedagógusok mindössze 4,7\%-a alkalmazza.

\section{Eszközök és eljárások}

A hospitálások során öt iskolában látogattunk földrajzórákat, tehát személyesen vettünk részt, mint passzív megfigyelők. Alkalmazott megfigyelési szempontjaink 
voltak: tanári módszerek, munkaformák, kommunikáció, tanulói aktivitás, figyelem, szemléltetés. A hospitálás kauzális és összehasonlító (Lengyelné, 2013), mivel az adatgyüjtés mellett további célunk az ok-okozati összefüggés feltárása és az iskolatípusok közötti különbségek megfigyelése volt. A hospitált óra után került sor egy egyéni interjúra a pedagógussal.

Ezen felül elkészítettünk két kérdőívet, amelynek célcsoportját a magyarországi földrajztanárok, majd a második mérés során bármilyen szakos pedagógusok alkották. A két mérés alatt összesen 314 fő töltötte ki az íveket. Elérésükben nagy segítséget nyújtott a virtuális tér, a Facebook csoportok. Az elsőben az oktatás akkori helyzetről, tanárok elégedettségéről, illetve az iskolák infrastruktúrájáról érdeklődtünk. 2020. tavaszán mélyebben kérdeztük a digitális oktatásról, feltételeiről, eredményeiről. A két kérdőívet átfedő kérdések esetén összehasonlítást végeztünk.

Ahhoz, hogy egységesebb képet kapjunk, általánosabb kiértékeléssel Falus Iván (2007) kategorizálását használtuk a módszerek besorolására (1. táblázat).

A második mérés során nemcsak a földrajz, hanem bármely más szakos pedagógus véleményét is mértük. Ezzel magyarázható az életkori sajátosságok változása, továbbá feltételezzük, hogy a kitöltés időtartama alatt az embereknek a korlátozások miatt, több idejük maradt az internet (Facebook) használatra
1. táblázat: Oktatási módszerek csoportositása Falus (2007) osztályozása alapján (forrás: a Szerzőo)

\begin{tabular}{|c|c|c|}
\hline \multicolumn{3}{|c|}{ INFORMÁCIÓ FORRÁSA SZERINT } \\
\hline Verbális & $\begin{array}{l}\text { Szemlél- } \\
\text { tetés }\end{array}$ & $\begin{array}{l}\text { Gyakorlati } \\
\text { módszerek } \\
\text { (tanulók által } \\
\text { megismerő } \\
\text { tevékenység) }\end{array}$ \\
\hline \multirow{2}{*}{ Szóbeli } & \multirow{5}{*}{ Vizuális } & Receptív \\
\hline & & Reproduktív \\
\hline \multirow{3}{*}{ Írásbeli } & & FelfedezŐ \\
\hline & & Heurisztikus \\
\hline & & Kutató jellegü \\
\hline \multicolumn{3}{|c|}{$\begin{array}{c}\text { OKTATÁS LOGIKAI IRÁNYA } \\
\text { SZERINT }\end{array}$} \\
\hline \multicolumn{2}{|c|}{ Induktív } & Deduktív \\
\hline \multicolumn{3}{|c|}{$\begin{array}{l}\text { TANULÁSI MUNKA IRÁNYÍTÁSA } \\
\text { SZERINT }\end{array}$} \\
\hline $\begin{array}{c}\text { Tanári } \\
\text { dominanciájú }\end{array}$ & \begin{tabular}{|c|} 
Közös \\
tanári- \\
tanulói \\
dominan- \\
ciájú \\
\end{tabular} & $\begin{array}{c}\text { Tanulói } \\
\text { dominanciájú }\end{array}$ \\
\hline \multicolumn{3}{|c|}{ DIDAKTIKAI FELADATOK SZERINT } \\
\hline $\begin{array}{c}\text { Új ismeretek - } \\
\text { képességek } \\
\text { tanítása/tanú- } \\
\text { lása }\end{array}$ & $\begin{array}{l}\text { Alkalma- } \\
\text { zás }\end{array}$ & $\begin{array}{l}\text { Rendszerezés/rögzí- } \\
\text { tés }\end{array}$ \\
\hline \multicolumn{3}{|c|}{$\begin{array}{c}\text { SZÓBELI KÖZLŐ MÓDSZEREK } \\
\text { SZERINT }\end{array}$} \\
\hline Monologi & kus & Dialogikus \\
\hline
\end{tabular}




\section{Eredmények, megvitatás}

Első hipotézisben feltételeztük, hogy az oktatásban a változatos módszer és munkaforma alkalmazása hatékonyabb elsajátítást eredményez. Ennek megállapítására egy diagnosztikus tesztet készítettünk. Az ismeretalapú diagnosztikus teszten a legjobb eredményt azok az iskolák érték el, ahol a látogatott tanórán $8 \mathrm{db}$ módszerrel tanított a tanár, és azok közül is a sokoldalú szemléltetés volt a dominánsabb, a szóbeli módszerek 50\%-os használata mellett (Homoki és Simonyi, 2020). Nem nagy az elért eredmények közötti szórás iskolánkként, s úgy tűmik. hogí a változatosabb módszerek/munkaformák alkalmazása mélyebb elsajátítást eredményez.

A második hipotézis szerint az infrastrukturális berendezések hiánya ronthatja az oktatás színvonalát, és nehezítheti az ismeretek elsajátítását. Azokban az iskolákban, ahol van interaktív tábla (hospitált iskolák közül $4 \mathrm{db}$ rendelkezik ilyenekkel), a diákok sokkal jobban élvezték az órákat (tanulói attitűd kérdőív eredményei alapján: Simonyi, 2019), mivel ők is használhatták és elmondásuk szerint, segíti őket az újismeretek rögzítésénél, rendszerezésénél (például: összefoglalás sorn). Nem minden iskola engedheti meg magának az okostábla használatát, ezért ott más eszközök jelennek meg, ilyen például a számítógép, projektor, ami a videók, képek bemutatására alkalmas. Van olyan iskola, amelyik nem rendelkezik projektorral termenként, ezért ott a tanároknak előre meg kell tervezni a tanórát, és eldönteni, hogy mikor ki fogja használni a digitális eszközöket. Ezáltal döntôen a frontális szóbeli módszereket alkalmazzák, amelyet különböző csoportmunkákkal tudnak kiegészíteni. Az az iskola teljesített a legkevésbé jól, ahol nincs lehetőség az interaktív tábla használatára, és projektorból is kevés van. Ezt alátámasztja a diagnosztikus teszt eredménye is.

A megvizsgált kérdések újabbakat vetettek fel, melyek megválaszolása további vizsgálódást igényelt. Azonban egyre inkább az a kép rajzolódik ki, hogy a legmeghatározóbb elem egy tanulási folyamatban maga a két főszereplő: a diák és a tanár. Kettőjük közös munkája dönti majd el ennek sikerességét is.

Ahhoz, hogy a tanárok a kor igényeihez igazodó magas színvonalú órát tudjanak tartani, megfelelő eszközökre és kipihentségre is szükségük van. Lannert-Sinka 2009-es kutatási eredményeivel egybehangzóan a kutatási eredmények is azt bizonyítják, hogy a tanároknak a túlterheltség jelenti a legnagyobb problémát (2. ábra).

A 2009-es kutatás szerint a megkérdezett pedagógusok 10\%-a a heti kötelezô óraszámnál kisebb túlterheltségről adott választ, míg 30\%-uk jóval magasabb óraszámban tanít. Ezek az értékek alacsonyabbak, mint jelen kutatás eredményei, bár azóta eltelt 10 év. Az aktív pedagógusok harmada túlterhelt, ami két fő tényezőből tevődik össze: az egyik a munkáltató által előírt többletórákból, a másik a magánórákból adódik (Lannert- 
2. ábra: Az alábbiak mekkora gondot jelentenek az Önök iskolájában? (forrás: a Szurrố)

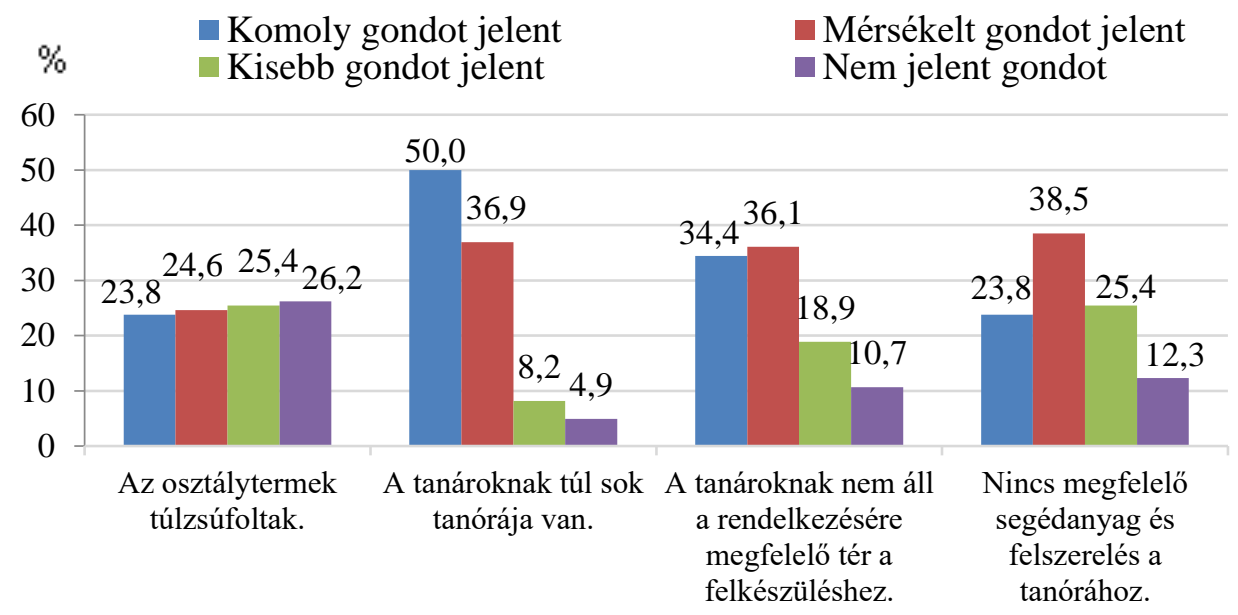

Sinka, 2009). Sajnos ez a jelenség összeköthető azzal, hogy egyre kevesebb a tanár, és óraadóként is dolgozniuk kell több iskolában, amellett magánórákat is vállalnak, hogy az alacsony keresetüket kiegészítsék. Ettől lehetnek kimerültebbek, ingerlékenyek és nehezebben választják az újabb módszerek alkalmazásának előkészítését. A minőségi oktatást még befolyásolja, hogy a tanároknak nem áll a rendelkezésükre megfelelő tér (2. ábra) és környezet (megfelelő méretű tanári, asztal, természetes fény, irodalmak) a felkészüléshez, és ehhez még hozzáadódik, hogy a megfelelő eszköz hiánya is hátráltatja az élvezetesebb órák tartását. A termek nagysága a megkérdezettek szerint nem jelent akkora gondot, mint az előbb említett három tényező.

A tanítás és az oktatás során (főként földrajzórákon) napjainkban a felgyorsult információáramlás miatt fontos az IKT eszközök alkalmazása, ehhez szükséges a számítógép használata. A mai világban elkerülhetetlen, hogy egy pedagógus tudja kezelni a számítógépet. A számítógép használattal kapcsolatos hozzáértés szubjektív megítélésének egy ötfokozatú Likert-skálával (az 1. kategória „,nem értek hozzá”, az 5. kategória „teljesen értek hozzá") történő mérése alapján 108 fô (88\%) gondolja úgy, hogy ért a számítógéphez, ez a 4. és 5. kategória összevonásával kapott érték. A számítógépeket főként az adminisztrációhoz, az órai felkészüléshez és tanórákon is használják. A számítógép és az IKT eszközök egy kisegítő alkalmazás, mert ezzel lehet motiváltabbá tenni a tanulókat, illetve a tanulóknak meg kell tanulniuk térben és időben elhelyezni információkat virtuálisan is. Ha azt halljuk, hogy IKT (információs és kommunikációs technológia), gyakran nem gondolunk másra, mint a 
számítógépekre, interaktív táblákra, de maga a megnevezés magában foglal minden digitális technológiát (Farsang, 2011). Az oktatásban ilyen az írásvetítő, projektor, számítógép, interaktív tábla stb.

Ma már a gyerekek többsége készség szinten használja a számítógépet, amely lehet előny is olyan szempontból, hogyha ezáltal próbáljuk ismertetni az órai anyagot, az vonzóbb lesz számukra. A pedagógusoknak az IKT használata során több problémával kell szembenézniük (Farsang, 2011). Ilyen például „,a technikai tudás és a magabiztosság hiánya; a tanulók több készséggel rendelkeznek a tanárnál, a technológia dominancia veszélye, egyenlő hozzáférés biztosítása" (Farsang, 2011, 152 o.).

Az egyik népszerű IK'T eszköz az interaktív tábla. Ez egy szoftver segítségével összeköti a számítógépet a táblával (Net2). A hagyományos táblával szemben előnye, hogy a táblaképek már a számítógépen előre elkészíthetőek, majd az óra végén, a táblán történt mozzanatokat is el lehet menteni. Földrajzórákhoz Pajtókné dr. Tari Ilona által létrehozott netszköszkészlet (http:// netszkozkeszlet.ektf.hu/) ad segítséget, amelyben egy virtuális dolgozószobába lépünk be. Ott megtalálunk mindent, amire szükségünk lehet egy földrajz óra keretein belül (óraterveket, ásványokat, animációkat, térképeket, játékokat). Megemlítendő még Havassy András honlapja (https://www.havassyandras. hu /tanul\%C3\%A1ssal-kapcsolatos-blogja im), amely szintén sok földrajzórára vonatkozó animációt, videót tartalmaz. A Havassy Andrással készített interjúban, megkérdeztük, mi volt a célja a honlap megalkotásával? „Elsősorban saját magamnak kezdtem el összegyüjteni a legjobb linkeket (könyvjelzőként). Főként azért is, hogy az óráimat élvezetesebbé tegyem. Ezért törekszem arra, hogy folyamatosan frissítve legyen. Örülök neki, hogy több kollegám is használja a „honlapomat” (Havassy, 2018).

Szilassi Péter: A földrajz új világgal című gyűjteménye (Farsang, 2011) is hasznos segítség lehet.

Óralátogatások során lehetőség volt olyan órák hospitálására, ahol a tanárok interaktív táblát alkalmaztak. A diákok nagyon élvezték, ugyanis kimehettek a táblához, animációkat, videókat, jelenségeket mutattak be az adott órán, az új ismeretek feldolgozásánál, a feldolgozott ismeretek alkalmazásánál, ellenőrzés, értékelés, illetve az ismeretek rendszerezésénél egyaránt. Sajnos nem minden iskola engedheti meg magának az interaktív táblák használatát, mivel eléggé drága a beszerzésük, de erre néhány évvel ezelőtt volt pályázati program. Nagy gond a „nem tudom használni” vagy „a szoftvert vásárolni jogtisztán” problémaköre is (az interjú alanyok véleménye szerint 60\%). Volt olyan iskola is, akik rendelkeznek ilyen táblával, de az idősebb tanárok nem értenek hozzá, így csak kivetítőként funkcionál. Négy iskolában jelen volt, akár csak egy teremben is az interaktív tábla, ami nem rossz arány, 
hiszen országosan sokkal rosszabb a helyzet (Tóth, Molnár és Csapó, 2011).

Összefoglalva: lényeges, hogy a tanórákon szemléltessünk is a szóbeli közlési módszerek alkalmazása mellett. Bármilyen anyagot tanítunk, fontos, hogy képeket, ábrákat, videókat vigyünk az órára, mivel az élvezetesebbé, látványosabbá és érdekesebbé, érthetőbbé teszi a tanórát a tanulóknak, így a tanár is sikerélményhez jut, ami motiváltabbá teheti mindkettőjüket. A bevésődést, a megszilárdulást is segíti a több érzékcsatorna használata (Barta, 2007).

Azért tartottuk fontosnak a kutatás (2019) ezen részét kiemelni, ugyanis az IKT szerepe a 2019/2020-as tanév tavaszi félévére teljesen átértékelődött. A tanulási környezet megváltozásának oka a koronavírus (COVID-19) világjárvány megjelenése volt. Ez volt az az idő, amikor mindenki számára az egészsége, családja és biztonsága vált a legfontosabbá. A globalizált világban a digitális eszközök kerültek előtérbe. A legtöbben otthonról (Home Office) dolgoztak, otthonról tanultak. Így a számítógépnek nem csak oktatási, órai felkészülés, szemléltetés volt a funkciója, hanem maga a tanítás helye is. Az infrastruktúrából adódóan, nagyon sok iskola, főleg diákok nem rendelkeztek (nem rendelkeznek) megfelelő minőségú és mennyiségű felszereltséggel az online tanításhoz. Sok helyen az online platformon történő oktatás nem tudott megvalósulni.

A digitális oktatás felváltotta a hagyományos iskolai életet. Nem a „katedrális” oktatást folytatták a tanárok, hanem a virtuális térbeli oktatás jelent meg. Mindenki a legjobb tudása szerint próbálta rövid idő alatt kifejleszteni, kiépíteni a legmegfelelőbb módot arra, hogy a diákok számára élvezetes, egyben eredményes órákat tudjanak tartani. Ez egy hatalmas kihívás volt mindenki számára. Az előző kutatás során már kiderült, hogy a tanári pálya elöregedőben van. Egyre kevesebb fiatal választja a tanári/pedagógusi pályát. A digitális oktatás komplikáltabb helyzetet teremthetett az idősebb kollegák számára. Választás nem volt; az országban minden oktatási intézménynek kötelező volt átállnia a digitális oktatásra. Számos felületet lehetett e célból találni az interneten. Valaki a Google Classroom-ot használja, más a Microsoft Teams-et, Skype, Discord, YouTube, Zoom stb. felületeket. Ahogy már korábban említésre került, ennek vizsgálatára szintén készítettünk egy online kérdőívet.

Elmondható, hogy a pedagógusok kb. 30\%-a saját megítélése szerint sikeresen teljesítette az oktatás céljait (3. ábra). Ezt vélhetően köszönhetik többek között annak is, hogy a diákok kimondottan szeretik a különböző virtuális, valamint IKT eszközök által tartott tanórákat. Minden iskolában, minden tanár különböző online felületet alkalmazott az oktatásra. Ezzel sokkal színesebbre és egyben változatosabbra sikeredett a tanórájuk a diákoknak. Ezért is mond-ható, hogy a diákok némelyike sokkal jobban teljesített a második félévben. 
3. ábra A tanárok sikeressége a digitális oktatás céljainak megvalósitásában saját megitélésük szerint (forrás: a Szerző).

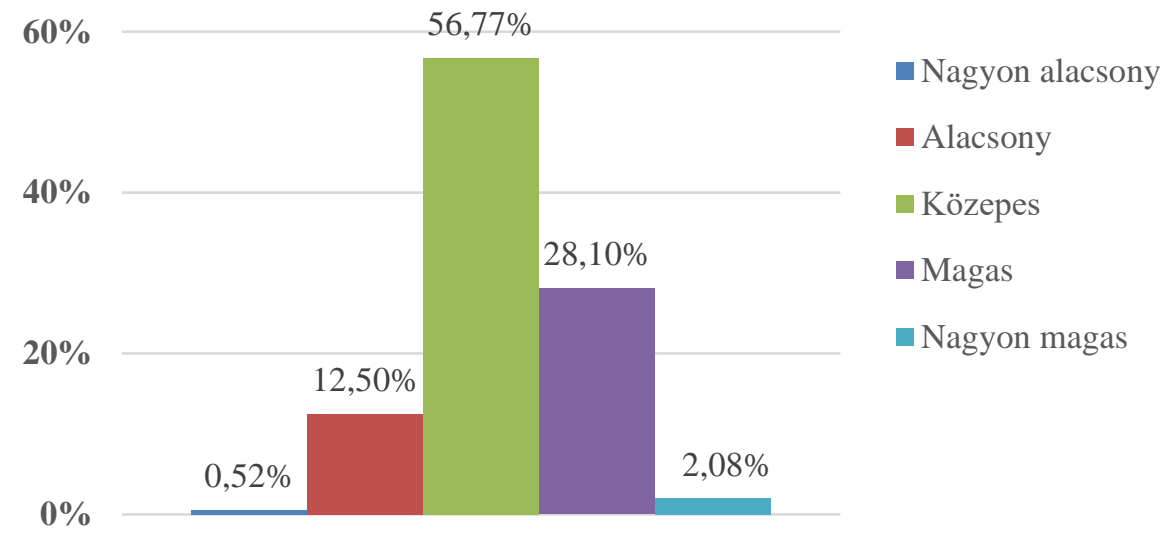

- Véleményünk szerint ezt tovább segítette még, hogy a szabadidős tevékenységek lecsökkentek, így a diákoknak több idejük maradt a tanulásra (is). Megjegyzendő, hogy a pedagógusok mintegy 60\%-a közepesnek, $13 \%$-a pedig nagyon alacsonyak ítélte saját sikerességét.

A legtöbben az ellenőrzésre az időkorlátos tesztlapot alkalmazták. Erre megfelelő felület a Redmenta, Google űrlap, Moodle stb. Megjelenik elég nagy számban az önálló projektmunka, amelyet sokszor a hagyományos módszerek mellett (frontális oktatás és páros munkaforma) a kontakt oktatásban nem alkalmaznak (4. ábra).

Összességében elmondható, hogy az oktatási intézmények közel 68\%-a segítette a pedagógusok munkáját az új digitális, online oktatás során. Biztosított számunkra leírást, tájékoztatást, de a kitöltők 25,5\%-a számára próbaórák megtartását is biztosították (5. ábra)

\section{4. ábra Pedagógusok által alkealmazott iskolai} számonkérés a digitális oktatás során Forrás: a Szerzó)

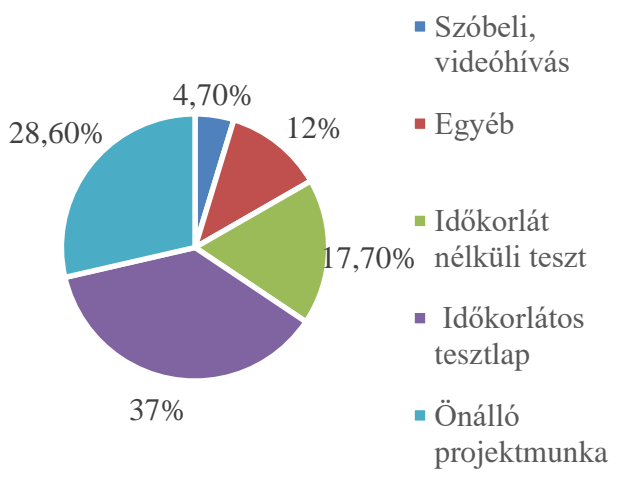


5. ábra Az Önök iskolája az új IKT esұközö̈k beszerzése esetén biztosit-e felvilá-gositást, leirást, információt a pedagógusok számára? Forrás: a Szerzo"

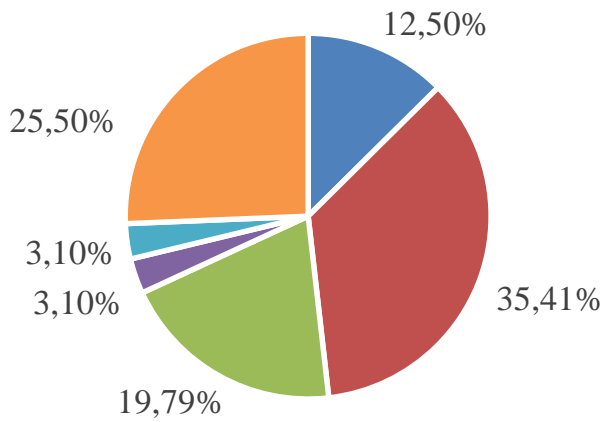

- Biztosítanak leírást

- Kaptunnk felvilágosítást

- Képzéseket, próba órákat tartanak számunkra.

- Nem biztosítanak leírást.

Szokás mondani, hogy minden rosszban látható szófelhőbe gyűjtöttük össze. van valami jó, és ez fordítottan is igaz. Megjelent például a diákok önállóságára Kíváncsiak voltunk, hogy a pedagógusok való nevelése, életre nevelés, nincs milyen pozitívumot látnak a távok- helyhez kötve, digitális eszközök tatásban, online oktatásban. A leggya- ismeretek fejlesztése mind a diákok, mind koribb megjelölt fogalmakat a 6. ábrán a tanárok számára stb. (6. ábra).

6. ábra Szófelhö tanári szemmel: a digitális oktatás pozitivumai (forrás: a Szerzőo)

több internetes platform ismerete

egyéni haladás

rutinkeveseb b stress Z =

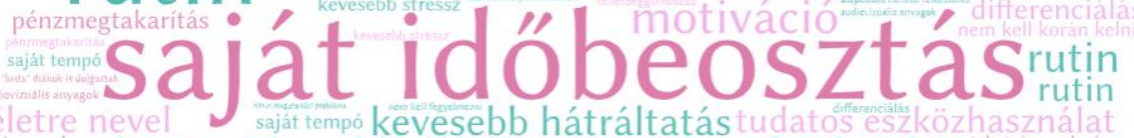
interaktív digitális kompetencia fejlódése

nincs helyhez kötve diákok megtanúlnak tanulni

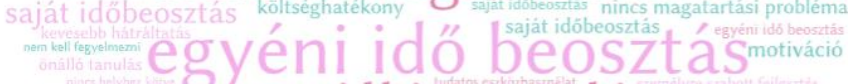

motiváció önálló tanulás kényelmesebb

kényelmesebb 
A válaszadók 31,25\%-a jelölte meg pozitív hatásként az időbeosztást (például: önálló időbeosztás, időkorlátozás nélkül van lehetősége a tanulónak tanulni, utazási idő megspórolása), míg 23\% szerint az oktatási felületek megismerésével fejlődik a digitális képessége a tanulóknak és a pedagógusoknak egyaránt, továbbá lehetôséget nyújt az eredményesebb óra megtartásához (például: a zárkózottabbak is megnyilvánulnak, könynyebb és biztosabb a szemléltetés stb.).

Természetesen a negatívumok sem maradnak el (7. ábra). Főként a gyermekek hiányát, számonkérés lehetetlenségét, az elmaradó tanári magyarázatokat, visszacsatolásokat, valamint a pedagógus hiányát fogalmazták meg a legtöbbször a válaszadók. A válaszadók 38\%-a nevezte meg a személytelenséget, a szociális kapcsolat hiányát, míg az oktatásbeli nehézségeket (tanórai aktivitás, számonkérés) 28\%-uk említette.

\section{Korlátozások}

A kutatás első része egy 2018-2019-ben kapott eredmény, amely nem kimondottan a mai tanári kompetenciát méri fel. E rövid idő alatt képesek voltak a pedagógusok jelentősen fejlődni a digitális tanítás színterén (Nyitrai, 2021). Meg tudtak ismerkedni újabb online felületekkel, a számítógépekkel, okostáblákkal. Miután elkészült a 2020. évi felmérés, lehet kevesebb különbséget kaptunk volna a digitális készéggel kapcsolatban.

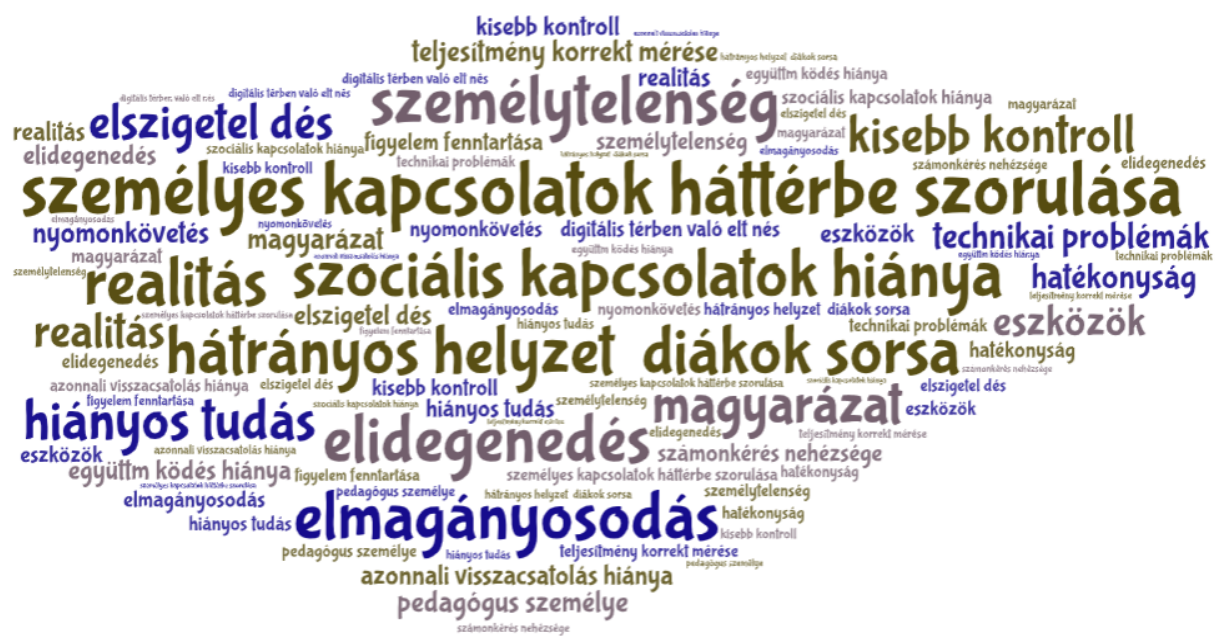


A tanulmányban régi, 2009-es adatra történt hivatkozás a tanárhiányt illetően, amelyet egy 2018. november 5-én megjelent Eduline cikk is megerôsít, miszerint: több, mint 600 tanárt keresnek a Klebelsberg Központ által fenntartott és működtetett iskolákba, a Közszolgálati Állásportálon található álláshirdetések alapján (Net7). Továbbá Magyarországon a természettudományi tantárgyakat lehet alapképzési, illetve diszciplináris végzettséggel oktatni, amely szintén arra utal, hogy egyre kevesebb a természe-tudományokat elvégző pedagógus.

\section{Konklúzió}

Tanulmányban bemutatásra kerültek az általunk készített két kérdőíves felmérés eredményei, amelyek hipotézisei és kérdései az alábbiak voltak:

Az első hipotézis szerint az oktatásban a változatos módszer és munkaforma alkalmazása hatékonyabb elsajátítást eredményez. Ez a megállapítás a diagnosztikus teszt iskolánkénti átlagos eredményei, továbbá a hospitálási napló által rögzített módszertani összefoglaló által bebizonyosodott.

Második kutatási kérdés, hogy az infrastrukturális berendezések hiánya ronthatja az oktatás színvonalát, és nehezítheti az ismeretek elsajátítását, melyhez több alkérdés is tartozott. Kutatási eredmény szerint, az az iskola teljesített a legkevésbé jól a diagnosztikus teszt során, ahol nem volt lehetőség az interaktív tábla hasz- nálatára, továbbá a projektorok száma is korlátozott volt az intézményben.

A hipotézisek alátámasztása során szignifikáns különbséget csak a számítógép használatnál találtunk az adminisztrációnál. A hipotézis vizsgálata a varianciaanalízissel történt. Azt néztük meg, hogy a korcsoportokban milyen mértékben tér el a válaszok számtani középértéke. Konkrétan az egy szignifikáns különbség az alábbi: a 20-29 évesek mindegyike használja adminisztrációra a gépet. A 4049 évesek 96\%-a, a 30-34 évesek 94\%-a, az 50-59 évesek 90\%-a, használja adminisztrációra. A különbség szignifikáns: $F=2,505$ és $p<0,034$.

A többi területen is vannak eltérések, de ezek nem szignifikánsak az 5\%-os szinten.

\section{Köszönetnyilvánítás}

Köszönetemet fejezem ki a földrajz szakos tanárok és a magyar közoktatásban dolgozó pedagógusoknak a kitöltött kérdőívek miatt, valamint az öt iskolának, ahol hospitálhattunk, a diagnosztikus tesztet, tanulói kérdőívet vehettünk fel.

Köszönettel tartozom Apró Annának, aki a digitális kutatás során segítette szakmai munkánk sikerességét. Hálás vagyok Dr. Schmercz Istvánnak is, aki az SPSS rendszer méréseiben nyújtott segítséget.

\section{Irodalom}

Babbie, E. (2003): A társadalomtudományi kutatás gyakorlata. Balassi Kiadó, Budapest. 
Bárdos J. (2012): A tantárgy - pedagógiák szerkezete, megitélésük kritériumai. Letöltés: 2021.04.08. Web: http:// misc.bibl.u-szeged.hu/14214/1/mp_ 2012_002_6539_061-075.pdf

Barta T. (2007): Informatikai eszközöke basználata a földrajzoktatásban. Kézirat. Debrecen.

Falus I., és Ollé, J. (2000): Statisztikai módszerek pedagógusok számára. OKKER Kiadó, Budapest.

Falus I. (2007): Didaktika. Nemzetei Tankönyv Kiadó, Budapest.

Farsang A. (2011): Földrajztanitás korszerüen. GeoLitera, Szeged. Az információs-Kommunikációs Technológiák (IKT) és a földrajzoktatás pp. 149-155.

Forgó S., Hauser Z. és Kis-Tóth, L. (2001): Médiainformatika. Líceum Kiadó, Eger.

Hajdu M. (2020). Egyre idösebb tanárok küzdenek egyre problémásabb gyerekekekel az iskolákban. Letöltés: 2021.03.23. Web:

https://g7.hu/kozelet/20200228/egyr e-idosebb-tanarok-kuzdenek-egyre-

problemasabb-gyerekekkel-aziskolakban/)

Homoki, E. és Sütő, L. (2014). Studying the public opinion of geography as a subject and its knowledge elements: a case of Hungary Journal of Baltic Science Education 13: 4 pp. 508-522., 15 p.

Homoki, E., és Simonyi, S. (2020). Comparative Analysis of the Methods of Teaching Geography in Different Types of Schools. Journal of Applied
Technical and Educational Sciences jATES. pp 1-5.

K. Nagy E. (2015/b). KIP könyv I.-II. Miskolci Egyetemi Kiadó, Miskolc.

Lannert J. és Sinka E. (2009). A pedagógusok munka- és munkaidó terhelése. Letöltés: 2018.12.10. Web: http://www.okm.gov.hu/letolt/kozok t/ped_teher_kut_besz_090205.pdf)

Lengyelné Molnár T. (2013). Kutatástervezés. Eszterházy Károly Főiskola, Eger. Az interjú. p. 109-117. Letöltés: 2020.04.11. Web: http://mek.oszk.hu/14400/14492/pd f/14492.pdf)

Makádi M., Farkas B. és Horváth G. (2013). Tanulási - tanitási technikák a földrajztanitásban. Budapest, ELTE.

Simonyi S. (2019). A földrajzoktatás módszereinek összebasonlitó vizsgálata különböző típusú iskolákban. Kézirat. Esztergom.

Ütőné Visi J. (2011). Mérés-értékelés a földrajzoktatásban. Educatio Kht. Hallgatói Információs Központ.

Tóth E., Molnár Gy. és Csapó B. (2011). Az iskolák IKT felszereltsége - belyzetkép országos reprezentativ minta alapján.

Letöltés: 2019.01.07. Web: https://www.researchgate. net/publication/291718988_Az_iskol ak_IKT-felszereltsege__helyzetkep_orszagos_ reprezentativ_minta_alapjan

\section{Internetes források:}

Net1: A HVG 2020-as középiskolai rangsora: újra a dobogó tetején a 
Fazekas. Letöltés: 2021.03.23. Web: https:/ / eduline.hu/kozoktatas/20191 006_kozepiskolai_rangsor_2020

Net2: Mi a digitális vagy interaktív tábla? Letöltés: 2018.12.27. Web:

http://okt.ektf.hu/data/forgos/file/ta nanyag/

05_ikt_innovaciok/621mi_a_digitlis_v agy_interaktv_tbla.html

Net3: Lehet, hogy kialvatlanság miatt kezelhetetlen a gyerek. Letöltés: 2018.12.10. Web: http://www.origo.hu/ egeszseg/20160218-gyerekkor-alvasalvasigeny-pszichologia-semmelweisegyetem-magatartastudomanyiintezet.html

Net4: Tanulási szokások. Letöltés:

2018.09.10. Web:

http://www.kerdoivem.hu/kerdoiv/8 58939475/1/
Net5: A tanár és szerepe a tanítás-tanulás eredményességében. Letöltés: 2019.01.05. Web: https://regi.tankonyvtar.hu/hu/tartal om/tamop412b2/20130002_didaktika/tananyag/JEGYZET18

3.3._A_tanar_es_szerepe_a_tan.scorm 1

Net6: Rettentő megterhelő és egyfajta kikapcsolódás is - diákok a digitális oktatás első hetéről. Letöltés: 2020.06.29. Web: https://eduline.hu/kozoktatas/20200 319_diakok_visszajelzesei_az_elso_het rol

Net7: Ebből van elege sok pedagógusnak: rengeteg adminisztráció, folyamatos helyettesítések. Letöltés: 2021.03.30. Web:

https://eduline.hu/kozoktatas/allami _iskola_pedagogus_MY955H 